\title{
Mucocoele and mucopyocoele of the frontal sinus penetrating to the cranial cavity and the orbit
}

\section{Śluzowiaki i śluzowiako-ropniaki zatok czołowych penetrujące do jamy czaszki i oczodołu}

Mariusz Maliszewski, Piotr Ładziński, Woiciech Kaspera, Krzysztof Majchrzak

Katedra i Oddział Kliniczny Neurochirurgii w Sosnowcu, Śląski Uniwersytet Medyczny w Katowicach

Neurologia i Neurochirurgia Polska 2011; 45, 4: 342-350

\begin{abstract}
Background and purpose: Mucocoele of the paranasal sinuses falls within the scope of interest for neurosurgery when erosion of the sinus wall and the osseous structures of the skull base develops and the lesion extends towards the cranial cavity, the orbit, the cavernous sinus or the sella turcica. The paper aims to present the method of treatment of extensive mucocoele which is used in our clinic.

Material and methods: We treated 7 patients ( 2 women and 5 men; age range: 27-68 years). Mucopyocoele was diagnosed in two cases, and mucocoele in the other five. In 5 cases, extension of the mucocoele to the cranial cavity and the orbit or to the ethmoid sinus and the orbit was observed. In the remaining 2 cases, mucopyocoele extended to the ethmoid sinus, the sphenoid and maxillary sinuses, cranial cavity and the orbit. The purpose of surgery was to remove the mucocoele or the mucopyocoele and to prevent recurrence.

Results: The postoperative course in all 7 patients was uneventful. All symptoms gradually receded. No relapse was observed in any patient during a follow-up period that varied from 10 months to 8 years; nor did incidents of inflammation of collateral sinuses occur.

Conclusions: The treatment of mucocoele or mucopyocoele of the frontal sinus penetrating to the cranial cavity and the orbit consists of the following stages: cranialization of the frontal sinus, complete resection of the mucosa, tight closing
\end{abstract}

\section{Streszczenie}

Wstęp i cel pracy: Śluzowiak zatok przynosowych staje się przedmiotem zainteresowania neurochirurga, gdy dochodzi do erozji ściany zatoki i struktur kostnych podstawy czaszki z penetracją w kierunku jamy czaszki, oczodołu, zatoki jamistej lub siodła tureckiego. Celem pracy jest prezentacja metody leczenia rozległych śluzowiaków stosowanej w ośrodku autorów.

Materiał i metody: Materiał obejmował 7 pacjentów -2 kobiety i 5 mężczyzn w wieku 27-68 lat. U 2 chorych rozpoznano ropniaka zatoki, u pozostałych 5 chorych treść śluzowiaków była jałowa. W 5 przypadkach stwierdzono penetrację śluzowiaka do jamy czaszki i oczodołu lub do sitowia i oczodołu, w pozostałych 2 przypadkach śuzowiako-ropniak rozprzestrzeniał się do sitowia, zatoki klinowej, szczękowej, jamy czaszki i oczodołu. Zasadniczy zabieg operacyjny miał na celu usunięcie śluzowiaka lub śluzowiako-ropniaka oraz ostateczne zabezpieczenie przed jego nawrotem.

Wyniki: U żadnego chorego nie obserwowano powikłań pooperacyjnych, a obrzęk powiek i okolicy czołowej, wytrzeszcz gałki ocznej i niedowład nerwu okoruchowego stopniowo się wycofywały. W okresie obserwacji od 10 miesięcy do 8 lat u żadnego pacjenta nie stwierdzono cech nawrotu choroby, nie powtórzyły się też incydenty zapalenia zatok obocznych nosa. Wnioski: Zaopatrzenie rozległego śluzowiaka lub śluzowiako-ropniaka zatoki czołowej penetrującego do jamy czaszki

Correspondence address: dr n. med. Mariusz Maliszewski, Katedra i Oddział Kliniczny Neurochirurgii, Śląski Uniwersytet Medyczny w Katowicach, Wojewódzki Szpital Specjalistyczny nr 5 im. św. Barbary, Pl. Medyków 1, 41-200 Sosnowiec, phone + 48323682 024, fax +48 323682550 , e-mail: sekrnch@wss5.pl

Received: 14.08.2010; accepted: 14.02.2011 
of the frontal-nasal duct, and separating the air space of the opened collateral nasal sinuses from the cranial cavity with a large pedicled periosteal flap.

Key words: mucocoele, mucopyocoele, frontal sinus, periosteal flap.

\section{Introduction}

Mucocoele of the paranasal sinuses is defined as a slowly growing, cystic entity formed by inflamed mucoperiosteum of the sinus. It develops in a sinus due to the pathological accumulation and retention of mucus subsequent to the inflammatory process within mucous membrane of the sinus with concomitant orifice blockage $[1,2]$. If an inflammatory process follows, it can result in rapid expansion of the mucocoele [2]. Whenever infection of the retained discharge occurs, it results in mucopyocoele or even pyocoele of the sinus, which poses a threat of infectious, intracranial complications. Mucocoele might arise in any paranasal sinuses, but the most common localizations are the frontal sinus $(65 \%)$ and anterior ethmoid sinus (30\%), while mucocoele of the maxillary sinus is relatively rare (3-10\%). Mucocoeles of the posterior ethmoid sinus and sphenoid sinus are extremely rare (approximately 1\%) [1,3-5].

Mucocoele falls within the scope of interest of the neurosurgeon whenever an erosion of the sinus wall and the osseous structures of the skull base develops with subsequent penetration of the lesion towards the cranial cavity, the orbit, the cavernous sinus or sella turcica $[4,6,7]$.

The authors present selected cases of extensive mucocoele and mucopyocoele of the frontal sinuses that penetrated into the orbit and cranial cavity treated surgically with a pedicled periosteal flap.

\section{Material and methods}

Our cohort consisted of seven patients, two women and five men aged 27 to 68 years. Clinical signs suggestive of mucocoele or mucopyocoele in four patients had occurred 3 to 4 months prior to the proper final diagnosis, while in the other three patients they lasted for 1 to 3 years. Most of the cases presented with recurrent headaches and eye pain with concurrent progressive exophthalmos and/or palpebral oedema. Simulta- i oczodołu wymaga usunięcia treści i torebki śluzowiaka, kranializacji zatoki czołowej, doszczętnego usunięcia błony śluzowej ze ścian zatoki, szczelnego zamknięcia otworu czołowo-nosowego i oddzielenia przestrzeni powietrznej otwartych zatok obocznych nosa od jamy czaszki obszernym uszypułowanym płatem okostnowym.

Słowa kluczowe: śluzowiak, śłuzowiako-ropniak, zatoka czołowa, płat okostnowy.

neous loss of visual acuity was present in four cases; correspondingly, four patients presented with oculomotor nerve paresis. One of the patients had developed nasal liquorrhoea 2 months prior to hospitalization. Four patients were treated for chronic sinusitis for 3 to 30 years, two of them surgically; one of the patients underwent surgical treatment three times. Two of the patients at admission presented with acute sinusitis of the frontal sinuses; prior to the definite surgical treatment, sinus drainage and targeted antibiotics had been implemented. Mucocoele contents in all other cases were sterile.

Diagnosis in all cases was based on cranial computed tomography (CT) and magnetic resonance imaging (MRI). Three cases with destruction of the floor and the posterior wall of the frontal sinus along with the medial wall of the orbit presented with penetration of mucocoele into the cranial cavity and orbit. Two other patients showed signs of destruction of the floor of the sinus and the wall of the orbit with subsequent penetration of the mucocoele into the orbit and ethmoid sinus, while the remaining two patients had a mucopyocoele that extended from the frontal sinus into the ethmoid, sphenoid and maxillary sinuses along with the cranial cavity and the orbit. On top of that, two patients presented with the destruction of the frontal wall of the sinus with resulting purulent fistula in one of them.

Surgical management in all of the seven cases aimed at the complete removal of the mucocoele or mucopyocoele and permanent protection against their recurrence.

The surgical technique in all of the cases involved a skin incision along the coronary suture with subsequent fine preparation of the pedicled galeo-cutaneous flap along the eyebrow ridge. Meticulous attention was paid to preservation of the connective tissue layer that exists between the galea and pericranium adjacent to the pericranium in order to ensure its maximal thickness. Neurovascular bundles remained untouched within the galeo-cutaneous flap; close attention was paid to the frontal muscular complex as well in order to ensure 

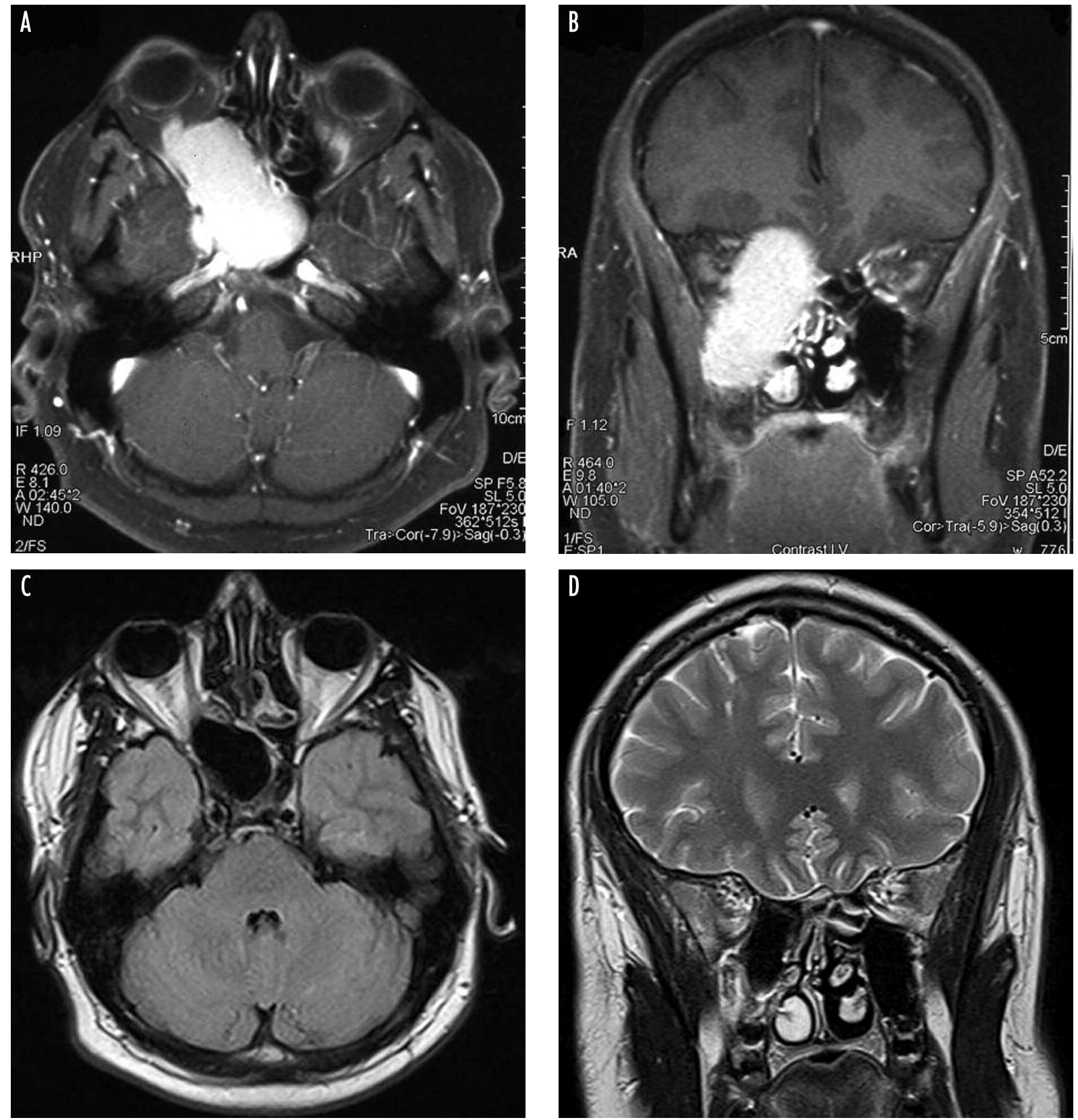

Fig. 1. Mucopyocoele of the lower part of the right frontal, an ethmoid, right maxillary and sphenoid sinus that penetrates the right orbit and anterior cranial fossa. Follow-up - 2.5 years. $A, B$ - mucopyocoele on preoperative MRI; C, D - mucopyocoele resection outcome on the postoperative MRI

proper facial mimics in the frontal region. Next, the pericranial flap, pedicled along the eyebrow ridges, was separated from frontal bones; whenever a tear occurred, it was meticulously sutured. Upon completion of the frontal bones exposure, craniotomy followed - parabasal, bifrontal in three cases, which encompassed parabasal parts of frontal bones along with frontal sinuses; three other cases underwent transfrontal craniotomy via removal of the anterior wall of the frontal sinus. A single patient underwent right frontoorbital craniotomy. The next stage involved a thorough resection of the posterior wall of the frontal sinus, which usually had been damaged by the mucocoele or mucopyocoele beforehand. Mucous or purulent content was subsequently removed and all the visible structures were gradually depleted of inflammatory granulation, the mucocoele capsule and mucosa that lined the sinus. It is of particular importance to completely remove the remnants of 

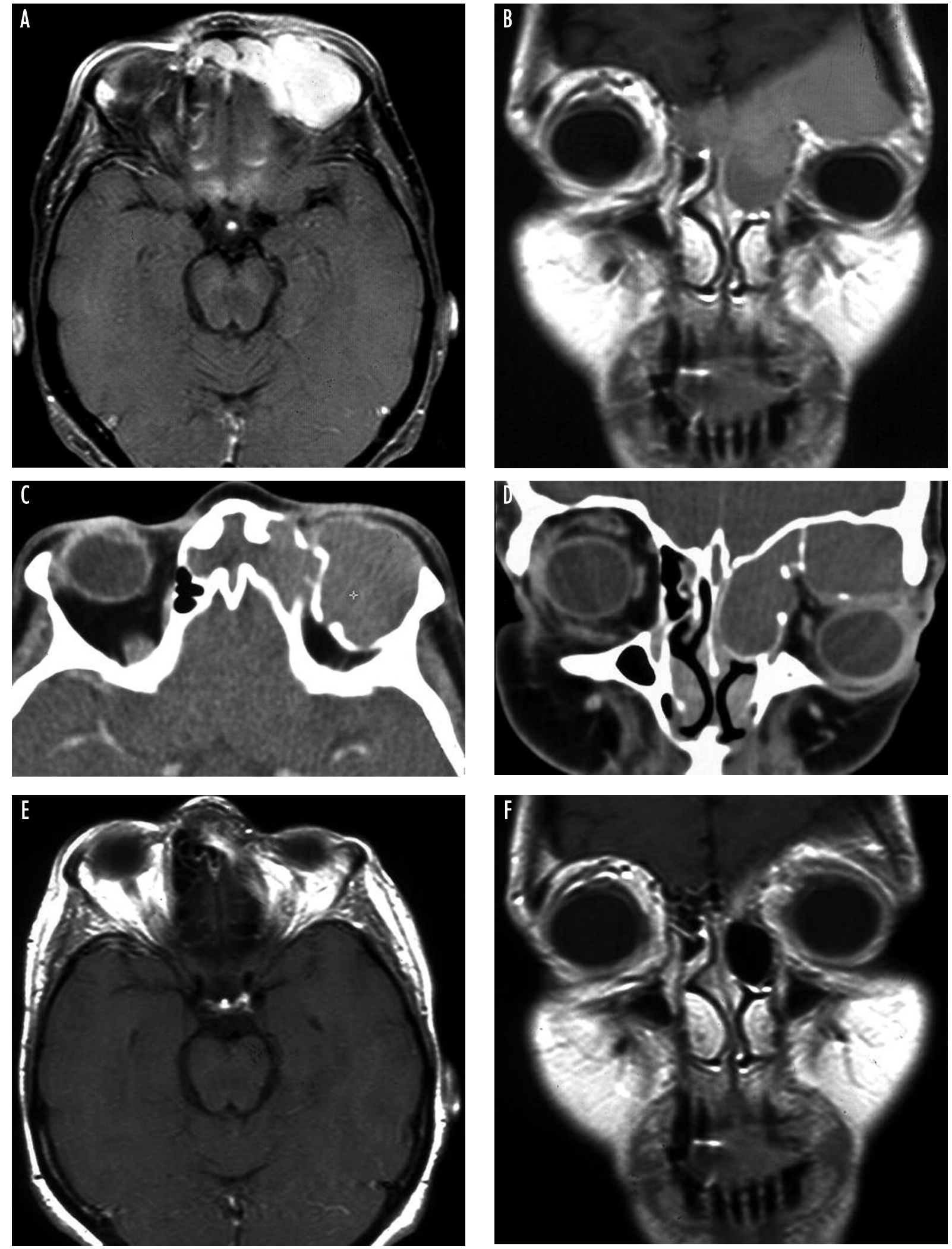

Fig. 2. Mucocoele of the left frontal, an anterior ethmoid, and upper part of the nasal cavity that penetrates the left orbit and anterior cranial fossa, causing significant deformation and destruction of the bony margins of the left orbit. Follow-up - 8 years. A, B - mucocoele on preoperative MRI; C, D-mucocoele on preoperative $\mathrm{CT}$; E, $\mathrm{F}$ - mucocoele resection outcome on the postoperative MRI 

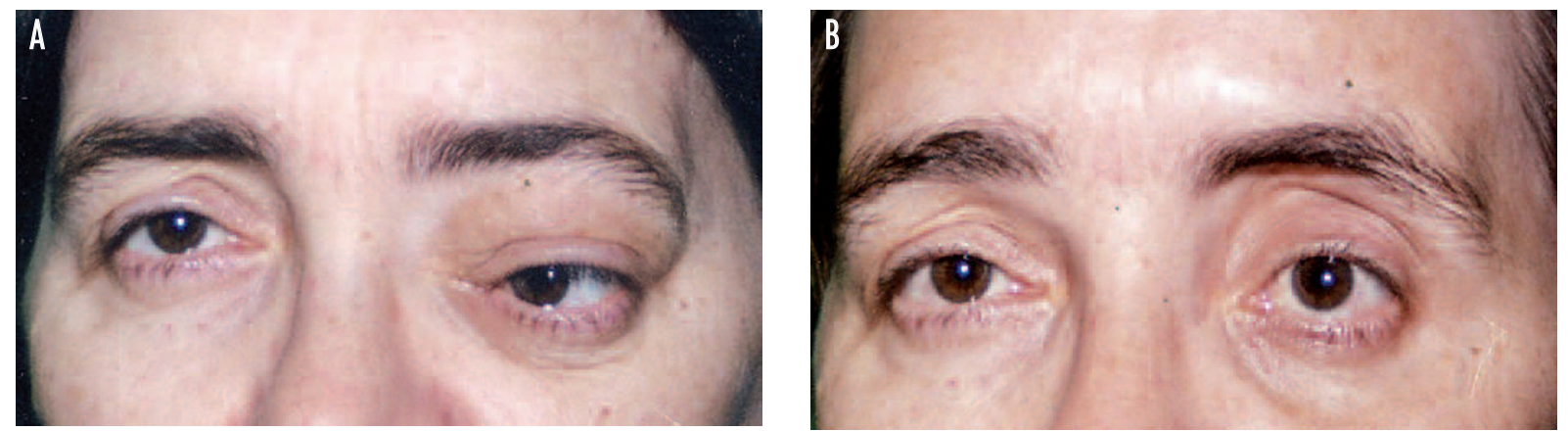

Fig. 3. Dislocation of the left eyeball due to mucocoele. A - preoperative status; B - postoperative status

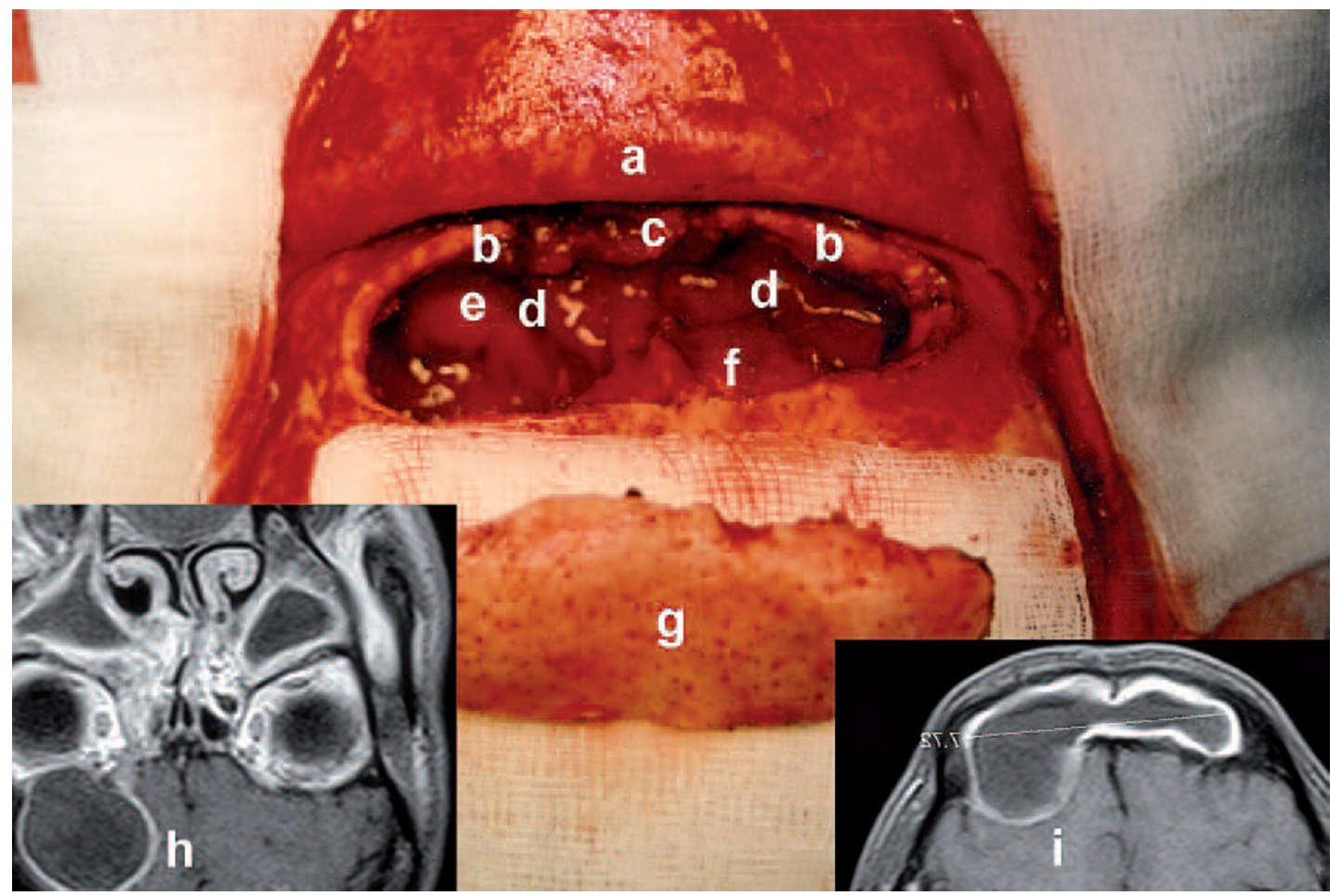

Fig. 4. Parabasal, bifrontal craniotomy that allows frontal sinus cranialization and provides insight on the skull base of the anterior fossa. a - pedicled, periosteal flap; $b$ - upper edge of the orbit; $c$ - base of the nose; $d$ - space resulting from frontal sinus cranialization; $\mathrm{e}$ - left orbit content; $f$ - right frontal region dura; $g$ - bifrontal bone flap; $h, i-$ preoperative MRI

mucous membrane and periosteum, especially in the lateral parts of the sinus where slotted recesses often occur. Then the whole surface of the sinus walls was deeply coagulated with monopolar coagulation and the internal lamina of the bone was obliterated with a high-speed drill and a diamond bit in order to ensure complete removal of the mucous membrane even from deep, bony recesses. Scrupulous attention was paid to the removal of mucous membrane and periosteum of the frontonasal duct. The whole operative field was abundantly flushed with antibiotic solution and bared walls of the sinus were then lined for several minutes with cottonoids soaked in antiseptic. The frontonasal duct was eventually closed with oxycellulose or bone chips collected at craniotomy. Filling of the postoperative cavity with subsequent lining of the frontal sinus floor and eventually an opened ethmoid sinus with a pedicled periosteal flap was a key stage of the procedure that ensured separation of the nasal cavity from the cranial cavity and the dura as well as orbital structures. The empty space above the periosteal flap was then filled with gentamicin foam that pushed the periosteal flap to the base of the anterior fos- 
sa. In one case that presented with rhinorrhea where the mucocoele involved the right frontal sinus, right orbit, ethmoid, sphenoid and maxillary sinuses and eroded dura over the ethmoid sinus, duraplasty with Tachosil ${ }^{\circledR}$ was performed. The whole base of the anterior fossa was sealed with a very extensive periosteal flap. At the closing stages of the procedure the bone flap was replaced and drainage underneath the cutaneous flap was maintained for 24 to 48 hours. All the patients with one exception received parenteral clindamycin, $600 \mathrm{mg}$ every 8 hours for 7 days postoperatively with another 7 days of oral administration. One patient according to preoperative culture received vancomycin for 14 days: 7 days prior to and 7 after the surgery.

\section{Results}

None of the patients presented any significant postoperative disturbances. All patients were discharged 7 days after surgery, following removal of the sutures with postoperative wounds healed. Palpebral oedema as well as frontal oedema, exophthalmos and oculomotor nerve palsy gradually diminished. No late postoperative complications were found. During a follow-up period that varied from 10 months to 8 years, no recurrence of the disease was observed in any of the patients; correspondingly, they had no incidents of sinusitis.

\section{Discussion}

Expansion of mucocoele or mucopyocoele within the paranasal sinuses might ultimately lead to erosion of the sinus walls followed by secondary penetration into the cranial cavity or orbit with their clinical sequelae, thus forcing an appropriate therapeutic strategy.

Destruction of the upper and posterior walls of the frontal sinus enables entrance into the anterior cranial fossa with resultant frontal lobe compression. Inferolateral expansion leads to destruction of the bony margins of the orbit with resultant dislocation of the eye bulb, exophthalmos, impairment of ocular motility with double vision and progressive loss of visual acuity [2].

Mucocoele of the sphenoid sinus, even though it is the most seldom one, remains extremely dangerous. If large enough it might compress and dislocate six upper cranial nerves, carotid arteries even in their intracavernous part, the pituitary gland and ultimately the hypothalamus. The most common symptoms include severe headaches related to the tension of the dura on the planum sphenoidale and skull base of the anterior fossa. Since sphenoid sinus mucosa enervation originates from the posterior ethmoid branch of the ophthalmic branch of the trigeminal nerve, the imparted pain might embrace the whole head. Ophthalmoplegia due to oculomotor nerve compression and vision loss related to optic nerve compression supervene then $[5,6]$. Mucopyocoele may additionally pose a risk of serious complications such as brain abscess, epidural and subdural empyema, severe meningitis, optic neuritis or cavernous sinus thrombophlebitis $[1,2]$.

Surgical treatment is an elective modality in these circumstances. Introduction of contemporary endoscopic techniques as well as intraoperative neuronavigation enabled minimally invasive management of these diseases. New procedures such as endoscopic frontal sinusotomy or endoscopic amputation of the septum and floor of the frontal sinuses (endoscopic modification of Lothrop method) are successfully implemented with very good outcomes [8,9]. Kennedy et al. [10] for the first time described successful implementation of endoscopic methodology in the treatment of mucocoele in 1989 in 15 out of 18 patients $(83.3 \%)$ with average postoperative follow-up of 17.4 months. Har-El [11] reported 108 cases of mucocoele treated endoscopically in 103 patients with an average follow-up of 4.6 years. The recurrence rate in this group averaged only $0.9 \%$. Khong et al. [12], on the other hand, described 24 cases of mucocoele with penetration into the orbit in 15 patients who underwent endoscopic intranasal drainage. In his group, four patients (27\%) required endoscopic revision for frontonasal duct narrowing and recurrent mucocoele. Intranasal drainage of mucocoele with orbital penetration constitutes a standard in specialized endoscopic centres, even in cases with erosion of the anterior wall of the frontal sinus [13]. A modified endoscopic Lothrop's method turned out to be efficient even in recurrent cases after unsuccessful open osteoplastic surgery. However, extensive experience of the surgeon as well as neuronavigation is essential in these cases [14].

All of the cases with extensive infectious erosion of bony structures within the skull base with concomitant epidural empyema or purulent meningitis, posttraumatic injuries of frontonasal drainage apparatus or large deficits of the anterior wall of the frontal sinus are not protected against progression of the disease and severe complications when a simple drainage of the cyst with antibiotic therapy is performed. In our opinion, extensive surgery that allows removal of the mucocoele with 
its capsule along with proper protection of the sinus against recurrence is warranted.

Bifrontal craniotomy is a standard neurosurgical procedure that facilitates access to the anterior fossa skull base in the treatment of tumours of the anterior skull base and frontobasal traumatic injuries. It should be performed parabasally with dissection of the anterior and posterior walls of the frontal sinus so as to minimize perioperative injury to the frontal lobes. Similarly, to avoid early or late complications such as rhinorrhea, ascendant infection or the development of mucocoele or mucopyocoele of the sinus, proper treatment of the sinus must be performed. Even a minor injury to the mucous membrane of the sinus might result in the development of mucocoele whenever sinus drainage is impaired. Mucocoeles have been reported 10,20 and even 40 years after primary injury of the mucosa $[4,15]$. Smoot et al. described a large mucocoele of the frontal sinus with cranial cavity penetration 14 years after facial injury during childhood that encompassed the incipience of the newly forming frontal sinus [16]. As mentioned before, risk factors for mucocoele development include: ongoing inflammation of the sinus mucosa with obstruction of its orifice due to chronic inflammation of the nasal and paranasal sinuses mucosa, polyps, allergy, anatomical variants of the nasal cavity walls, tumours of the nasal cavity and finally injuries, including iatrogenic ones $[1,3,5,9]$.

The main principle of the surgical treatment of the frontal sinus, whenever mucosa preservation is feasible, is to create a wide and proper drainage and ensure full airiness of the sinus. On the other hand, when extensive erosion of the anterior or posterior wall of the sinus and a sizeable injury to the frontonasal duct are present, this duct should be obliterated, mucous membrane totally removed and the lumen of the sinus eliminated with the complete removal of its posterior wall, i.e. cranialization. Both methods have their supporters as well as opponents [17-19]. In neurosurgical practice one usually faces cases with extensive damage to the walls of the frontal sinus that force a wide opening with anterior skull base access. The creation of a "safe sinus" in such a case must involve its cranialization.

Every cranialization of the frontal sinus must be completed by the filling of the post-sinusal space with some kind of material. Various methods of frontal sinus obliteration are related to the history of the material choices. Goodale and Montgomery described such a procedure for the first time in 1961 [20]. The wide range of indications for frontal sinus obliteration creat- ed then has decreased significantly with time. Simultaneously, a visible increase in the variety of materials for sinus obliteration has occurred. These materials might be roughly divided into three groups - autogenic, allogenic and synthetic. Autogenic materials include adipose tissue, muscle, spongy bone and periosteal flaps. Allogenic tissues such as lyophilized cartilage or bone were used for a short period but were rapidly abandoned due to the risk of transmission of other ailments. Polymethylmethacrylate (PMMA) is the most popular synthetic material but currently is being replaced by osteoconductive hydroxyapatite cement, which is a mixture of calcium tetra-phosphate and dicalcium phosphate [8], owing to the high risk of infection and rejection. The aim of sinus obliteration is elimination of the dead space on one hand and permanent isolation of the frontal sinus from the other sinuses below. Cases of dangerous volume reduction up to $50 \%$ when adipose tissue was used have been described $[21,22]$. It may result in the local renewal of diseased mucosa, late infectious complications or mucocoele formation. Muscle used as a filling undergoes extensive fibrosis that may result in significant size reduction of the graft. Rohrich et al. [15] in their experimental study compared the outcomes of frontal sinus obliterations with spontaneous osteogenesis, spongy bone, adipose tissue and muscle. All four methods allowed successful obliteration of the sinus; still the key rule of efficient obliteration was complete removal of the mucosa, periosteum and internal wall of the sinus walls with a high-speed drill and tight seal of the frontonasal duct. The authors proved that spontaneous osteogenesis that develops automatically following removal of mucosa, periosteum and scarification of the inner lamina of the bone is the most efficient one. No problems related to the harvesting of grafts, prolonged surgery or graft-harvesting site complications occur. These complications include haematoma, excessive oedema and infection resulting in pain and cicatrization in the graft-harvesting site [22]. Petruzzelli and Stankiewicz underline the importance of this factor as well [8]. Adipose tissue, muscle or spongy bone used in the infectious environment might serve as a good medium for bacterial growth [22]. Such a complication is less probable when a highly vascular pedicled periosteal flap is used. The periosteal flap contains skull periosteum and loose connective tissue that covers it, namely a subgaleal fascia according to Tolhurst. The subgaleal fascia is a structure built from three distinct layers - a central, compact one - fibrous layer that is covered by loose, reticular layers. The central layer has 
a rich vascular supply in the perimeter that originates from the supraorbital, supratrochlear, occipital, posterior auricular and temporal superficial arteries as well as from perforators from the adjacent galea. A combination of subgaleal fascia and periosteum provides a durable, highly vascular flap that is large enough to fill the frontal sinus. Some of the authors advise the extension of this flap with creation of a galeo-periosteal flap $[22,23]$. It is worth mentioning that a highly vascular flap reduces the risk of infection, especially when posttraumatic injury of the frontal sinus and anterior skull base requires repair. It is a material of choice in all of the cases with a primarily infected operative field such as mucopyocoele $[22,24]$. Our observations proved the aforementioned statement: all the presented cases recovered quickly and without any recurrences. In our department we routinely use a pedicled periosteal flap in skull base surgery in posttraumatic and oncological cases [24]. In cases with extensive destruction of the anterior fossa skull base the introduction of a vast periosteal flap imparts an adequate, i.e. watertight and immunologically competent, biological barrier that separates the dura from the paranasal sinuses.

Intraoperative and postoperative antibiotic therapy with abundant intraoperative irrigation of the field with antibiotic solution is of value. It reduces local bacterial flora, thus providing protection against postoperative infection $[8,25]$.

Polymethylmethacrylate (PMMA) is commonly used in skull reconstructive surgery, including frontal sinus anterior wall deficit repairs $[18,22]$. The use of PMMA, despite the fact that it is easily formed into an appropriate shape that fits the bony deficit margins, carries a number of inconveniencies. The major one is the high temperature generated during polymerization, which renders significant tissue reaction against the presence of the foreign body [8]. The incidence of complications in reconstructive surgery of frontobasal deficits with PMMA use is as high as $50 \%$ when PMMA is directly adjacent to paranasal sinuses mucosa [8]. Infection of the PMMA implant is an unconditional indication for its removal [26]. In our opinion, whenever a PMMA implant is contemplated, meticulous removal of mucosa and periosteum, if possible with mucosa lining the frontonasal duct, duct obliteration and exhaustive lining of the sinus floor with a pedicled, periosteal flap ought to be performed. Petruzzelli and Stankiewicz [8] described similar tactics for reconstruction of deficits of frontal sinus walls with hydroxyapatite cement. Hydroxyapatite cement as a graft material is far supe- rior to PMMA - most importantly it has osteoconductive properties, polymerizes at low temperature, and is gradually replaced by one's own bone without significant loss of volume, which completely prevents expansion of mucosa from the lower sinuses. Additionally it forms a mechanical barrier against bacterial infection thanks to its relatively small pores, approximately 2 to $5 \mathrm{~nm}$. According to Petruzzelli and Stankiewicz, it is an ideal material to be used in reconstructive surgery of infectious and posttraumatic deficits of frontal sinus walls. It appears that its only disadvantage is the high price [8].

Recent years have brought the first reports on endoscopic treatment of mucocoele and mucopyocoele with cranial cavity penetration. Bozza et al. [27] describe a group of 10 patients successfully treated endoscopically for mucopyocoele of the frontal sinus that translocated both frontal lobes and eye bulbs. Sautter et al. [28] in their paper present a much larger group of 57 patients that included 29 cases of mucocoele penetration into the orbit, 23 cases of anterior skull base erosion and 5 cases where both the orbit and skull base were eroded. Only $1.8 \%$ of patients had recurrent mucocoele but $17 \mathrm{pa}-$ tients $(29.8 \%)$ underwent endoscopic reoperations. These authors emphasize the significantly lower complication rate and less traumatic surgery in comparison to classic, open surgery. The main indications for open surgery according to Sautter et al. [28] are multilocular mucocoele and cases with extended and narrow lateral recesses of the frontal sinuses.

In our opinion, all of the cases described in these studies presented a much lower degree of destruction of skull base bony walls than those elected for our study. The endoscopic procedure does not create a barrier between the bared dura and mucocoele cavity. Taking into account a possibility of recurrence of mucopyocoele after endoscopic procedure, there is a risk of intracranial infectious complications. Some authors emphasize the necessity of long-term follow-up after endoscopic treatment of mucocoele [14].

\section{Conclusions}

1. Treatment of extensive mucocoele and mucopyocoele of the frontal sinus that penetrates into the cranial cavity and the orbit requires complete removal of the content and the capsule of the mucocoele, frontal sinus cranialization, complete stripping of the mucosa off the sinus walls, tight closure of the frontonasal duct and separation of the air space of the open paranasal 
sinuses from the cranial cavity with an extensive, pedicled periosteal flap.

2. The deficits of the anterior wall of the frontal sinus might be supplemented with hydroxyapatite cement, even in the infectious environment.

\section{Disclosure}

The authors report no conflict of interest.

\section{References}

1. Krzeski A. Śluzowiak zatok przynosowych. In: Krzeski A., Janczewski G. [eds.]. Choroby nosa i zatok przynosowych. Sanmedia, Warszawa 1997, pp. 222-228.

2. Palmer-Hall A.M., Anderson S.F. Paraocular sinus mucoceles. J Am Optom Assoc 1997; 68: 725-733.

3. Van Manen S.R., Bosch D.A., Peeters F.L., et al. Giant intracranial mucocele. Clin Neurol Neurosurg 1995; 97: 156-160.

4. Ehrenpreis S.J., Biedlingmaier J.F. Isolated third-nerve palsy associated with frontal sinus mucocele. J Neuroophthalmol 1995; 15: $105-108$

5. Hejazi N., Witzmann A., Hassler W. Ocular manifestations of sphenoid mucoceles: clinical features and neurosurgical management of three cases and review of the literature. Surg Neurol 2001; 56: 338-343.

6. El-Fiki M., Abdel-Fatah H.M., El-Deeb A.K. Sphenoid sinus mucopyocele with marked intracranial extension: a more common phenomenon in the Third World? Surg Neurol 1993; 39: 115-119.

7. Chua R., Shapiro S. A mucopyocele of the clivus: case report. Neurosurgery 1996; 39: 589-590.

8. Petruzzelli G.J., Stankiewicz J.A. Frontal sinus obliteration with hydroxyapatite cement. Laryngoscope 2002; 112: 32-36.

9. Dzhambazov K.B., Traykova N.I., Yuovchev I.P. Endonasal surgery in mucopyocele of the paranasal sinuses. Folia Medica (Plovdiv) 2001; 43:19-22.

10. Kennedy D.W., Josephson J.S., Zinreich S.J., et al. Endoscopic sinus surgery for mucoceles: a viable alternative. Laryngoscope 1989; 99: 885-895.

11. Har-El G. Endoscopic management of 108 sinus mucoceles. Laryngoscope 2001; 111: 2131-2134.

12. Khong J.J., Malhotra R., Wormald P.J., et al. Endoscopic sinus surgery for paranasal sinus mucocele with orbital involvement. Eye 2004; 18: 877-881.

13. Woodworth B.A., Harvey R.J., Neal J.G., et al. Endoscopic management of frontal sinus mucoceles with anterior table erosion. Rhinology 2008; 46: 231-237.

14. Langton-Hewer C.D., Wormald P.J. Endoscopic sinus surgery rescue of failed osteoplastic flap with fat obliteration. Curr Opin Otolaryngol Head Neck Surg 2005; 13: 45-49.

15. Rohrich R.J., Mickel T.J. Frontal sinus obliteration: in search of the ideal autogenous material. Plast Reconstr Surg 1995; 95: 580-585.
16. Smoot E.C., Bowen D.G., Lappert P., et al. Delayed development of an ectopic frontal sinus mucocele after pediatric cranial trauma. J Craniofac Surg 1995; 64: 327-331.

17. Zapała J., Saif F., Moskała M., et al. Wyniki zespołowego leczenia obrażeń zatok czołowych. Neurol Neurochir Pol 2006; 40: 376-385.

18. Day T.A., Meehan R., Stucker FJ., et al. Management of frontal sinus fractures with posterior table involvement: a retrospective study. J Craniomaxillofac Trauma 1998; 4: 6-9.

19. Goodale R.L., Montgomery W.W. Anterior osteoplastic frontal sinus operation: five years' experience. Ann Otol Rhinol Laryngol 1961; 70: 860-868.

20. Sharma G.D., Doershuk C.F., Stern R.C. Erosion of the wall of the frontal sinus caused by mucopyocele in cystic fibrosis. J Pediatr 1994; 124: 745-747.

21. Parhiscar A., Har-El G. Frontal sinus obliteration with the pericranial flap. Otolaryngol Head Neck Surg 2001; 124: 304-307.

22. Liu D., Michon J., Choio J. Galeal flap: clinical application in periorbital and orbital reconstruction. Ophthal Plast Reconstr Surg 1996; 12: 273-278.

23. Ioannides Ch., Freihofer H.P., Friens J. Fractures of the frontal sinus: a rationale of treatment. Br J Plast Surg 1993; 46: 208-214.

24. Maliszewski M., Ładziński P., Idzik M., et al. Zastosowanie uszypułowanego płata okostnowego w plastyce podstawy dołu przedniego czaszki. Neurol Neurochir Pol 1998; 32: 563-571.

25. Brook I., Frazier E.H. The microbiology of mucopyocele. Laryngoscope 2001; 111: 1771-1773 .

26. Manson P.N., Crawley W.A., Hopes J.P. Frontal cranioplasty: risk factors and choice in cranial vault reconstructive material. Plast Reconstr Surg 1986; 77: 888-904.

27. Bozza F., Nisii A., Parziale G., et al. Transnasal endoscopic management of frontal sinus mucopyocele with orbital and frontal lobe displacement as minimally invasive surgery. J Neurosurg Sci 2010; 54: 1-5.

28. Sautter N.,B. Citardi M.J., Perry J., et al. Paranasal sinus mucoceles with skull-base and/or orbital erosion: is the endoscopic approach sufficient? Otolaryngol Head Neck Surg 2008; 139: 570-574. 